\title{
THE IMPLEMENTATION OF CURRICULUM 2013 IN TEACHING ENGLISH AT SMPN 8 PADANG
}

\author{
WIDYA JULI ASTRIA
}

Volume 1 Nomor 1

JIPS ISSN: 2579-5449

\begin{abstract}
This research was aimed to find out the implementation of Curriculum 2013 in term of preparation, teaching learning process and assessment. The location of the research was at SMPN 8 Padang. The research used descriptive method. The data were taken through documentation, observation and field notes. The documentation of this research was the lesson plans designed by the teachers. Then, the researcher did observation to find out the process and assessment in the classroom. The result of this research showed that there was $88.21 \%$ of the lesson plans had been designed by the teachers based on the requirements of Curriculum 2013. But, in the teaching and learning process there were only $65 \%$ of aspects in the 2013 Curriculum have been implemented in teaching learning process. From the finding, it showed that $55 \%$ of activities in observing, questioning, associating steps had been done by

activities in experimenting steps had been done by teachers. Then, there were $75 \%$ of activities in communicating step had been done well by the teachers. It indicated that the teachers still got problems in implementing observing questioning, and associating steps. Then, the teachers tended to use observation, project, portfolio, and oral test to assess students' competences. Based on the findings above, it is shown that the aspects of Curriculum 2013 have not been implemented by all the teachers. Therefore, the English teachers of SMPN 8 Padang should learn more about how to implement Curriculum 2013 in teaching English. It is suggested to the head master to conduct more training for all English teachers on the Curriculum 2013 implementation. For next researcher, it is suggested to research the implementation of Curriculum 2013 with more samples to get further information..
\end{abstract} the teachers. Meanwhile, there were $65 \%$ of

Keywords: implementation, curriculum 2013, teaching English 


\begin{abstract}
ABSTRAK
Penelitian ini bertujuan untuk mengetahui penerapan kurikulum 2013 oleh guru yang mengajar di kelas VII SMPN 8 Padang. Ada tiga aspek yang dilihat yaitu persiapan guru, proses belajar mengajar dan penilaian yang dilakukan guru di dalam kelas. Penelitian ini menggunakan metode deskriptif. Data di ambil melalui dokumentasi, observasi dan catatan lapangan. Dokumentasi untuk penelitian ini adalah RPP yang di buat oleh guru. Kemudian, peneliti melakukan observasi langsung untuk melihat kegiatan dan penilaian yang dilakukan oleh guru di dalam kelas. Kemudian, peneliti juga membuat catatan lapangan untuk mendukung hasil observasi peneliti. Hasil penelitian menunjukan bahwa $88,21 \%$ RPP yang dibuat oleh guru sudah sesuai dengan aspek

belajar mengajar menunjukan hanya $65 \%$ tahaptahap pembelajaran yang diterapkan oleh guru dan dalam penilaian guru guru cenderung untuk menggunakan observasi, proyek, portfolio dan tes lisan. Berdasarkan penelitian yang dilakukan, dapat disimpulkan bahwa Kurikulum 2013 belum diterapkan oleh semua guru bahasa Inggris yang mengajar di kelas 7 di SMPN 8 Padang. Oleh karena itu, guru disarankan untuk mempelajari lagi tentang kurikulum 2013. Untuk itu, disarankan kepada Kepala Sekolah untuk menyelenggarakan pelatihan Kurikulum 2013 untuk semua guru Bahasa Inggris di SMPN 8 Padang. Dan untuk peneliti selanjutnya, diharapkan untuk bisa melakukan penelitian lebih lanjut dengan sampel yang lebih luas untuk mengetahui penerapan Kurikulum 2013.
\end{abstract} dalam kurikulum 2013. Akan tetapi dalam proses

\title{
I INTRODUCTION
}

As noted by Wiles \& Bondi (2007: 36), Curriculum represents a set of desired goals or values that are activated through development process and culminate in successful learning experiences for students. In addition, Ornstein and Hunkins (1998: 54) state Curriculum as a plan for providing sets of learning opportunities for persons to be educated. It means that Curriculum is planned and implemented to help students in learning process.

Previously, School-Based Curriculum was used at schools, but since academic year 2013/2014, the Curriculum 2013 has been implemented in some schools in Indonesia. The Curriculum 2013 is developed based on the competencies to be achieved by the students. The students are expected to be able to face the challenges in the future; to have good personalities and attitudes; to be responsible citizens (Husamah and Setyaningrum, 2013: 97). The changing of School-Based Curriculum to the

Curriculum 2013 is based on the government's commitment to fix the system and Curriculum in Indonesia.

In order to implement Curriculum 2013 in teaching English, there are three aspects of teaching that should be done by the teachers. They consist of teaching and learning preparation, teaching and learning process and assessment itself. It will be explained as follow:

Teaching and Learning Preparations

To get the successful teaching, the English teachers have to design lesson plan as the guidance for teaching. Thus, they can evaluate whether the objective of the material can be reached or not. If the teacher does not prepare well, the teaching will not run well.

According to Permendikbud No. 65 the year of 2013, there are ten components that should be existed in lesson plan namely subject matter, core competence, basic competence, indicator for competency achievement, 
instructional goal, teaching material, teaching methods, teaching steps and assessments. To find out whether the lesson plan which is designed by the teachers is designed well or not, there are five aspects that should be dealt with. Mulyasa (2009: 239) proposes those aspects as (1) formulation of learning objectives, (2) selection and organization of teaching materials, (3) selection of learning resources or media (4) learning methods, and (5) assessment. Those aspects will be used as indicators for this research in order to find out the quality of lesson plan designed by the teachers.

Teaching and learning Process

Before conducting the lesson, the teachers had prepared the lesson plan. The lesson plan designed by the teachers was applied in the classroom. As stated in the lesson plan, in teaching and learning process, the teachers have to do three activities namely pre-activity, whilstactivity and post-activity. In the pre-activity, Mulyasa (2013:101) notes that the teachers will probe students' knowledge and motivate them through interesting material which encourages them to know new things. There are several activities can be done by the teachers namely starting the learning process through asking students about things they know and understand; motivate students through interesting material which is useful for their life; and encourage student to know new things and to be interested in it.

Then, in whilst-activity there are five procedures of Scientific Approach should be conducted as suggested by Kemdikbud (2013) namely observing, questioning, experimenting, associating, and communicating. According to Kemdikbud (2013), Scientific Approach is an approach to enrich knowledge which is based on the scientific method. In addition, Scientific Approach also notes as the usual process of finding out information in science which involves testing ideas by performing experiments and making decisions based on the results (online Longman Dictionary, 2013). It means that the learning process should be based on intuition, common sense, prejudice, discovery with trial and error, and critical thinking.
The last components of teaching and learning process in the class is post-activity. As proposed by Amri (2013: 55), in post activity, the teacher should do some activities namely make a conclusion about the lesson; do an evaluations or reflection to the previous activities consistently; give feedback to the learning result and process; plan the further activities namely remedial, individual or group work; give information about the next material.

As the main point of Curriculum 2013 implementation in teaching learning process, the steps of scientific approach which will be explained as below:

Observing

Based on the Syllabus of Curriculum 2013, the teacher can do several observing step. The teachers ask the students to observe pictures, video or power point. The teachers can start the lesson by giving some questions. Then, the teachers ask the students to observe the picture of the Farm and link it with the previous lesson. Moreover, the teachers stimulate students to give their opinion through asking several questions. Through this step, the students will be able to make analysis about material given by the teacher. This step helps students to fill their curiosity about things. The students will able to find facts by themselves. The priority of this step is to create meaningful learning, so the students will be enjoyed and challenged. There are several activities can be done by the students in observing step namely reading, listening, pay attention to the material and identify the characteristic of material given. In this step, the teachers have to train students to be serious, patient, careful, and able to differentiate between general and specific information, and then to be able to think analytically, critically, deductively and comprehensively.

Questioning

Through the teachers' guideline as mentioned in the Permendikbud no. 81a, the students will be able to give some questions about the material given. The questions from students can be about their misunderstanding about material or their curiosity to get additional information. In this step, the teachers have to 
train students to be creative and able to give critical questions. Then, the students are also expected to develop their curiosity in order to help them to be smart person and ready to face the challenges in the future.

Experimenting

Dealing with the Syllabus of Curriculum

2013, the teachers are hoped to train students to be careful, honest, respectful, and appreciate other's opinion. It is hoped that the students will be able to communicate with other and get further information. The information can be got from the other sources namely through reading, or interview some informants. The students are also expected to observe their environment and link the information with their learning material.

Besides, it is also supported by Permendikbud no. 81a (2013) which expect the teachers to invite the students to do an experiment, ask the students to find information from other sources, observe the object/ event/ activity, and interview with informants. From this activity, the students are hoped to collect information from various sources, concern about phenomenon or object which is observed, even doing observation by themselves.

Associating

Based on Permendikbud No. 81A year 2013, associating is learning activities to process the information collected from the observation's result. In this step, the students are expected to be able to categorize some ideas and associate some phenomenon to remind. Then, the students are hoped to collect and analyze information. Through this step, the teachers are expected to lead students to be honest, careful, discipline and be able to think inductively and deductively.

As mentioned by Kemdikbud (2013), there are several things should be concerned by the teachers to apply associating in the teaching learning process. Those are the teachers should prepare the lesson plan which is appropriate with the Curriculum demand, the teachers should explain the instruction simply and clearly, the material is arranged hierarchy, the teaching learning process should be led to the result which can be observed, the teacher have to correct the students' mistake directly, the instruction should be repeated by the students in order to make it understandable, the teachers assess the students based on their behavior, then the teachers should recorded or noted the students' progress.

Communicating

According to Permendikbud No. 81A Year 2013, communicating is activities to convey the result and conclusion of observation which based on analysis in the form of written, spoken or others. In line with it, Hosnan (2014: 76) states that in the communicating step, the students will convey their conclusion about the material given. It means that the students can share their thought in front of the class. They are expected to express their opinion clearly by using a good language. These activities can be done through writing or telling the information from the observing, questioning, experimenting and associating.

Based on the explanation above, it can be concluded that the teachers are expected to conduct successful teaching and learning process to implement Curriculum 2013. They have to do the teaching and learning process though three activities namely pre-activity, whilst-activity, and post-activity. Then, the process should be done by using Scientific Approach. Through this approach, the students are expected to be able to do observing, questioning, exploring, associating, and communicating during learning process as suggested by Kemdikbud (2013).

Assessment

As stated by Kunandar (2013: 35), assessment is a process to collect information about the students' development during learning process. The assessment is very important and useful in teaching and learning process. In line with it, Hart (1994: 57) states that assessment is a process to collect information about students' knowledge and performance. Through the assessment, the teachers can measure students' achievement in learning process. The teachers need to know the students' learning situation in order to make sure whether the students understand or not with the lesson. Hence, the assessment should be applied in a good way.

In the Curriculum 2013, the teachers need to apply authentic assessment in the classroom. As 
noted by the Permendikbud No. 65 the year of 2013, the learning process can be assessed by using authentic assessment in order to assess students' preparation, process and achievement. The authentic assessment is activities to assess students which concern to the real situation during the learning process or the students' achievement through various assessments (Kunandar (2013: 35). The result of authentic assessment can be used by the teachers to plan a remedial, enrichment, and counseling. Meanwhile, the result of authentic assessment also can be used as the guidance to fix the learning process in accordance with the standard of education assessment. In the teaching and learning process, there are three competences that should be assessed by the teachers namely attitude, skills, and knowledge competences.

Moreover, according to Permendikbud No. 66 the year of 2013, there are several assessments can be used by the teachers in the classroom. It can be in the forms of written or oral test, observation, self-assessment, attitude measurement, and assessment of a task, project, and portfolios. These assessments are used to measure three competences namely attitude, knowledge and, skill.

Based on the description of the assessment above, it is known that authentic assessment can be applied in the forms of written or oral test, observation of performance, selfassessment, attitude measurement, assessment of a task, story-telling, writing samples, project/exhibition, experiments/ demonstrations, constructed-response items, teachers' observation and portfolios. While, in Curriculum 2013 only use several of them namely written or oral test, task-assignment, individual or group project, performance test, project, portfolio, observation, self-assessment, peer-evaluation, and journal.

In fact, as a new curriculum, there were some problems found in implementing it. As stated by head of FSGI (Federasi Serikat Guru Indonesia), Itje Chodijah (Kompas, January 2014), the implementation of Curriculum 2013 had a lot of problems. First, the design process of the Curriculum 2013 was not transparent.
Second, the preparation for public test process was not as good as expectation. Third, the coordination among technical team was not running well. It could be seen from their discussion about Curriculum design that was not clear yet dealing with the textbooks and the evaluation system. Fourth, Kemdikbud decreased the target implementation from $30 \%$ of schools to the $2 \%$ of schools. Fifth, the slowness of guidebook distribution postponed the teachers' training. These lacks of preparation has been given disadvantage to the national education system.

Moreover, based on the researcher's informal interview with some English teachers, the researcher found that some English teachers still had problems in implementing Curriculum 2013. For instance, in designing lesson plan, teachers found some differences about the contents.

Besides that, the teaching steps consist of three steps, but it had big difference in whilstactivity step. In SBC, the teachers did some activities through exploration, elaboration, and conformation processes. While, in Curriculum 2013, the activities have to be done through Scientific Approach which consist of five steps starts from observing, questioning, experimenting, associating, and communicating. Furthermore, the teachers also got problems dealing with the assessment. There were three aspects that should be assessed by the teachers in the classroom. The teachers had to pay attention on each student's attitudes, knowledge and skills. Related to the discussion above, the researcher was interested to conduct a research in SMP Negeri 8 Padang. The school is one of the pilot projects of Curriculum 2013. Hence, the researcher expected to get further information about the implementation of Curriculum 2013 in teaching English in this school. Then, the researcher conducted this research which entitled "The Implementation of Curriculum 2013 in teaching English at SMP Negeri 8 Padang”. 


\section{METHOD}

This research was conducted by using descriptive method. It described the way English teachers implemented Curriculum 2013 in teaching English at SMPN 8 Padang. It started from preparation, process and assessment. This Research was conducted at SMPN 8 Padang. The informants for this research were the English teachers at SMPN 8 Padang. There were four English teachers who taught in the seventh grade. Then, the researcher also did document analysis and observation sheet. The document for this research was lesson plans which designed by the teachers based on Curriculum 2013.

From the criteria of the lesson plan evaluation sheet, the researcher was able to determine whether the lesson plan designed by the researcher was well-organized or not. In considering the score for each indicator, the researcher used the syllabus as the guidance and discussed it with one of the English teacher at SMPN 8 Padang.

The second instrument was observation. The researcher observed the English teachers in the classroom by using observation sheet to know their action in teaching and learning process. The observation was conducted during the teaching process in the classroom. The observation sheet contained the components which were involved in the process of teaching and learning based on Curriculum 2013. It was done by giving check on the observation sheet when the behavior appeared. It includes pre, whilst and post activity of teaching and learning process. The indicators in pre-activity are suggested by Mulyasa (2013: 101), indicators for whilst-activity are suggested by Kemdikbud (2013), Riduwan (2004), and Hosnan (2014), and indicators for post-activity are suggested by Amri (2013: 55). Then, to determine the criteria for each indicator, the researcher combined the Likert Scale and the aspect from each indicator. Furthermore, the indicators for assessments were combination from O'Malley and Pierce (1996: 12) and Permendikbud No. 66, 2013. There were three competences that should be assessed by the teachers, namely knowledge, skill and attitude.

In this research, some steps was used in collecting data to get information about the implementation of Curriculum 2013, they were documentation, observation and field notes. The documentation was done by the researcher to find out data about teachers' preparation. Then, the researcher did direct observation in order to collect the data about the teachers' activities in teaching learning process and assessments.

Field Note was used in order to record the way English teachers conducted activities related to the indicators of Curriculum 2013 implementation. It was conducted in order to help the researcher to complete information from the field.

To analyze the data in this research, the quantitative method was used to describe the teachers' activities in implementing Curriculum 2013. The analysis of quantitative was the analyzing the data in the form of numerical based on the result of observation sheet and document analysis of lesson plans. The data were collected from the lesson plan, observation and field notes. Then, the data were grouped based on indicators of teachers' preparation and observation checklist of teaching-learning process and assessments which were filled based on the scoring derived from the each aspect which appeared in the observation sheet and lesson plans evaluation sheet. After analyzing the data, the researcher did the interpretation about the data. The finding report was written as complete as possible. 


\section{FINDING AND DISCUSSION}

In this research, the researcher described the way English teachers at SMPN 8 Padang implement Curriculum 2013 in teaching English in the classroom. The researcher would concern about the preparation, process and assessment of Curriculum 2013 implementation at SMPN 8 Padang. The finding of this research will be explained as below:

Teaching and Learning Preparation

In this research, the researcher collected fourteen lesson plans which designed by the teachers. The teachers enclosed the complete media and assessment in each lesson plan. The teachers designed the lesson plans based on the standard of Curriculum 2013. It was supported by the data on the table below: Table 1: The description of percentage got from the lesson plans

\begin{tabular}{|l|l|}
\hline Aspects of lesson plans & Percentage \\
\hline 1. Formulation of learning objectives & 85.71 \\
\hline $\begin{array}{l}\text { 2.Selection and organization of } \\
\text { teaching materials }\end{array}$ & 89.28 \\
\hline 3. Selection of learning resources & 85.71 \\
\hline 4. Learning methods & 89.28 \\
\hline 5. Assessments & 91.07 \\
\hline Average & 88.21 \\
\hline
\end{tabular}

From the data above, it showed that the teachers had designed the lesson plans based on the syllabus and aspects as mentioned above. From lesson plans which collected by the researcher, it was found that there were $85.71 \%$ of the teachers designed the lesson plans based on the formulation of learning objective appropriately. There were $89.28 \%$ of the teachers selected and organized the teaching materials before teaching in the classroom. There were $85.71 \%$ of the teachers selected the learning resources appropriate with the learning objective and learning material. Then, there were $89.28 \%$ of the teachers explained the learning methods which would be used in the classroom. To assess the students' achievement in the classroom, there were $91.07 \%$ of the teachers enclosed the assessments on their lesson plans. From the findings, it can be concluded that there were $88.21 \%$ of the teachers designed the lesson plans based on the syllabus and aspects which were proposed by Mulyasa as explained above.

Teaching and Learning Process

In the teaching and learning process, there were three sub-indicators namely preactivity, whilst-activity, and post activity. The researcher observed the teachers' activities during teaching and learning process. The researcher came to the classroom to observe each teacher. The data from the observation checklist will be explained as follow:

Pre-activity: Warm-up and Apperception and the warm-up and apperception, there were five activities that should be done by the teachers namely (1) greets and checks the students' attendance, (2) prepares and motivates the students to follow the learning process, (3) asks the students about previous lesson, (4) introduces the material and explains its purpose and (5) conveys the material chronologically as stated in the syllabus.

From the finding, it can be concluded that almost of the teachers had done the preactivity, eventhough there were teachers who did not do the item no. 1 and 3. But overall, the preactivity had been done based on the indicators of this research.

Whilst-activity

In this step, the activities started from observing, questioning, experimenting, associating, and communicating. From the research, it was found that warm-up and apperception was done well by the teachers. Then, observing, questioning, associating were done sufficiently by the teachers. There were some activities did not do by the teachers in the classroom, yet. In the experimenting, communicating and reflection were applied in a good way by the teachers. Meanwhile, it can be generalized that the implementation of Curriculum 2013 in teaching English was done about $65 \%$ by the teachers. It can be said that the implementation of Curriculum 2013 in teaching and learning process had been implemented by 
the teachers in a good way based on the criterion of scientific approach implemented as suggested by Kemendikbud (2013). Eventhough, there were not all the teachers implemented it in the classroom. To make it clearer, the finding above can be generalized and described into percentage as below:

Table 2: The description of indicators' percentage during teaching learning process

\begin{tabular}{|l|l|l|}
\hline Sub-indicators & $\begin{array}{l}\text { No } \\
\text { item }\end{array}$ & Perc \\
\hline Warm-up and Apperception & $1-5$ & $80 \%$ \\
\hline Observing & $6-10$ & $55 \%$ \\
\hline Questioning & $11-15$ & $55 \%$ \\
\hline Experimenting & $16-20$ & $65 \%$ \\
\hline Associating & $21-25$ & $55 \%$ \\
\hline Communicating & $26-30$ & $75 \%$ \\
\hline Reflection & $31-35$ & $70 \%$ \\
\hline Average & & $65 \%$ \\
\hline
\end{tabular}

Assessment

Based on the Curriculum 2013, there were three kinds of competences that should be assessed by the teachers. Those are attitude competence, skills competence and knowledge

\section{CONCLUSIONS}

Based on the result of the research, the researcher can note some conclusions as stated below:

In Teaching Preparations

From the data of the research, it was found that there were $88.21 \%$ of lesson plans had designed based on the aspects of Curriculum 2013 appropriately.

Teaching and Learning Process

In conducting the teaching learning process, there were five steps of scientific approach that should be done. The research showed that the observing, questioning, associating step had been done sufficiently by the teachers. Meanwhile, the experimenting and competence. To assess these competences, there were several assessments could be used by the teachers in the classroom. The assessments were observation, self-assessment, peer-evaluation, journal, performance test, portfolio, written test, oral test, individual and project. The teachers used the assessments based on the need in every meeting. For further explanation, the researcher described the data on the table below:

Table 3: The data from Assessments

\begin{tabular}{|l|l|l|}
\hline NO & Assessments & Percentage \\
\hline 1 & Observation & $81 \%$ \\
\hline 2 & Self-assessment & $63 \%$ \\
\hline 3 & Peer-evaluation & $63 \%$ \\
\hline 4 & Journal & $75 \%$ \\
\hline 5 & Performance test & $69 \%$ \\
\hline 6 & Project & $81 \%$ \\
\hline 7 & Portfolios & $81 \%$ \\
\hline 8 & Written test & $63 \%$ \\
\hline 9 & Oral test & $81 \%$ \\
\hline 10 & Task assignment & $69 \%$ \\
\hline
\end{tabular}

From the table above, it can be claimed that the teachers tended to use observation, project, portfolios and oral test.

communicating had been done well by the teachers. These steps had been done in a good way by the teachers. It indicated that the teachers still got problems in implementing observing questioning, and associating steps.

Assessments

There are three competences that should be assessed by the teachers dealing with the students' attitude, skills and knowledge. In order to assess those aspects, the teachers should apply authentic assessment as suggested by Kemdikbud (2013). The result of the research showed that the teachers tended to use observation, journal, portfolios and oral test. 


\section{REFERENCES}

Amri, Sofan. 2013. Pengembangan \& Model Pembelajaran dalam Kurikulum 2013. Jakarta: PT. Prestasi Pustakarya.

Hart, D. 1994. Authentic Assessment: A Handbook for Educators. California, New York: Addison Wesley Publishing Company.

Hosnan. 2014. Pendekatan Saintifik dan Kontekstual Dalam Pembelajaran Abad 21: Kunci Sukses Implementasi Kurikulum 2013. Bogor: Ghalia Indonesia.

Husamah and Setyaningrum, Yanur. 2013. Desain Pembelajaran Berbasis Pencapaian Kompetensi: Paduan dalam Merancang Pembelajaran untuk Mendukung Implementasi Kurikulum 2013. Jakarta: Prestasi Pustakarya.

Kemdikbud. 2013. Pedoman Penilaian Hasil Belajar. Jakarta: Kemdikbud.

Pengembangan Kurikulum 2013. Paparan Mendikbud dalam Sosialisasi Kurikulum 2013. Jakarta: Kemdikbud.

Kunandar. 2007. Guru Professional: Implementasi Kurikulum Tingkat Satuan Pendidikan (KTSP) dan persiapan menghadapi sertifikasi guru. Jakarta: PT. Raja Grafindo Persada.

. 2013. Penilaian Autentik (Penilaian Hasil Belajar Peserta Didik Berdasarkan Kurikulum 2013). Jakarta: PT. Raja Grafindo Persada.
Mulyasa. 2009. Implementasi Kurikulum Tingkat Satuan Pendidikan, Kemandirian guru dan kepala sekolah. Jakarta: Bumi Aksara.

2013. Pengembangan dan Implementasi Kurikulum 2013. Bandung: PT. Remaja Rosdakarya Offset.

Ornstein, Allan C. and Hunkins, Francis P. 2009. Curriculum: foundations, principles, and issues $\left(5^{\text {th }}\right.$ ed). New York: Pearson International Edition.

Peraturan Menteri Pendidikan dan Kebudayaan Nomor 65 tahun 2013 tentang Standar Proses Pendidikan Dasar dan Menengah. Jakarta: Departemen Pendidikan dan Kebudayaan.

Peraturan Menteri Pendidikan dan Kebudayaan Nomor 66 tahun 2013 tentang Standar Penilaian Pendidikan. Jakarta: Departemen Pendidikan dan Kebudayaan.

Peraturan Menteri Pendidikan dan Kebudayaan Nomor 81a tahun 2013 Tentang Implementasi kurikulum. Jakarta: Departemen Pendidikan dan Kebudayaan.

Sugiyono.2007. Metode Penelitian Kuantitatif, Kualitatif dan $R \& D$. Bandung: Alfabeta. Wiles, J., 7 Bondi, J. 2007. Curriculum Development: A guide to practice $\left(7^{\text {th }} \mathrm{ed}\right)$. New York: Prentice Hall. 